\title{
ANTIMICROBIAL AND ANTITUBERCULAR EVALUATION OF SOME NEW 5-AMINO-1,3,4-THIADIAZOLE-2-THIOL DERIVED SCHIFF BASES
}

\author{
Kasetti Ashok BABU, ${ }^{\mathrm{a}, \mathrm{b}}$ Indrajeet SINGHVI, ${ }^{\mathrm{b}}$ Nagasuri RAVINDRA ${ }^{\mathrm{c}}$ and Afzal Basha SHAIK ${ }^{\mathrm{d}, *}$ \\ ${ }^{a}$ Research Scholar, Pacific Academy of Higher Education and Research University, Pacific University, Udaipur-313003, India; Dr. \\ Samuel George Institute of Pharmaceutical Sciences, Markapuram, Andhra Pradesh, India. Email: soku4u@gmail.com \\ ${ }^{\mathrm{b}}$ Pacific Academy of Higher Education and Research University, Pacific University, Udaipur-313003, India. Email: \\ indrajeetsinghvi@yahoo.com \\ ${ }^{c}$ MAK college of pharmacy, Moinabad, Hyderabad, Telangana, India. Email: nravi1965@gmail.com \\ ${ }^{\mathrm{d}}$ Vignan Pharmacy College, Vadlamudi-522213, Andhra Pradesh, India
}

In an effort to study the effect of 1,3,4-thidiazole based molecules on bacteria, fungal and tuberculosis species, we synthesized a series of Schiff bases (2a-2m) by reacting a variety of carbonyl compounds with 5-amino-1,3,4thiadiazole-2-thiol. Molecular structure of these compounds was retrieved by spectral methods and elemental analysis. All these compounds were evaluated for their antibacterial, antifungal and antitubercular activities employing standard biological protocols. The compounds $\mathbf{2} \mathbf{m}$ and $\mathbf{2 l}$ substituted with the electron withdrawing fluorine and nitro groups showed excellent inhibitory activity against Staphylococcus aureus, Aspergillus niger and Candida tropicalis with an MIC of $8 \mu \mathrm{g} / \mathrm{mL}$ whereas $2 \mathbf{i}$ containing the electron releasing dimethylamino group showed potent activity against Proteus vulgaris. Additionally, $\mathbf{2 m}$ along with $\mathbf{2 j}, \mathbf{2 k}$ and $\mathbf{2 l}$ also exhibited superior antimycobacterial activity than the standard pyrazinamide. The activity data for these compounds pave the way for the development of new antimicrobial and antitubercular drugs.

\section{INTRODUCTION}

Heterocyclic chemistry research is of interest to the medicinal chemists worldwide as most of the drug molecules contain heterocyclic nucleus. 1,3,4Thiadiazole is a privileged heterocyclic moiety present in many drug molecules including the antibacterials-sulfamethizole, cefazolin and cefazedone; antiprotozoal-megazol and carbonic anhydrase inhibitor diuretics-acetazolamide and methazolamide (Fig 1). 1,3,4-Thiadiazole derivatives are also reported to possess noteworthy anticancer, antibacterial, antifungal, antitubercular and antioxidant activities. ${ }^{1-12}$

Schiff bases (usually called as imines or azomethines) are a class of organic compounds formed due to the acid or base catalyzed dehydrative condensation of a carbonyl compound (aldehyde or ketone) with a primary amine. These compounds were first reported by the Italian naturalized chemist, Hugo Schiff. Schiff bases and their metal complexes were reported to possess remarkable antibacterial, antifungal, antiviral, antitubercular, anticancer and antioxidant properties. ${ }^{13-20}$

\footnotetext{
* Corresponding author: bashafoye@gmail.com
} 


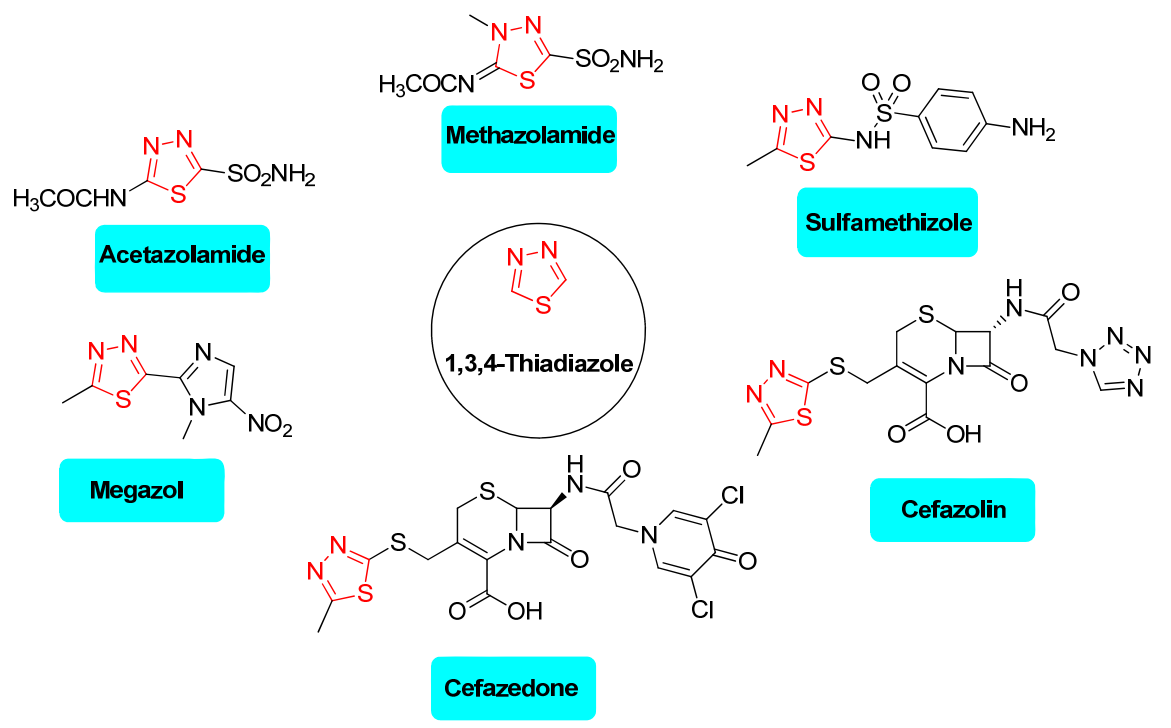

Fig. 1 - Marketed drugs containing 1,3,4-thiadiazole ring.

In view of the broad spectrum of the biological activities associated with 1,3,4-thiadiazole and Schiff bases the present work was aimed to prepare and evaluate the antibacterial, antifungal and antitubercular activities of some new 5-amino1,3,4-thiadiazole-2-thiol derived Schiff bases.

\section{EXPERIMENTAL}

\section{Materials and methods}

General: All the solvents and reagents used in the research were purchased from commercial suppliers and used without further purification. 5-amino-1,3,4-thiadiazole-2-thiol and the aldehydes and ketones were purchased from Sigma Aldrich Chemical Co. (Milwaukee, WI, USA). The progress of the reactions and the purity of the compounds were checked using precoated TLC silica gel $60 \mathrm{~F}_{254}$ plates (Merck KGaA, Darmstadt, Germany). The melting points of the purified compounds were determined on a Boetius melting point apparatus (expressed in ${ }^{\circ} \mathrm{C}$ ) (Rapido, Dresden, Germany), and are presented uncorrected. Samples were dissolved in chloroform $\left(\mathrm{CDCl}_{3}\right)$ and the $1 \mathrm{H} \mathrm{NMR}$ and $13 \mathrm{C}$ NMR spectra were recorded using TMS as an internal standard on Bruker 400 Avance NMR spectrophotometer. The chemical shift values are expressed in parts per million (ppm). Carlo Erba 1108 elemental analyzer was used for determining the elemental composition of $\mathrm{C}$ and $\mathrm{H}$.

\section{Chemistry}

General protocol for the synthesis of Schiff bases (2a-m): To a solution of 5-amino-1,3,4-thiadiazole-2-thiol ( $1 \mathrm{mmol})$ in dichloromethane (DCM), $1 \mathrm{mmol}$ of corresponding carbonyl compound was added. To the above solution a catalytic amount of anhydrous $\mathrm{MgSO}_{4}$ was added and stirred on a magnetic stirrer at room temperature for about 2-4 hours. ${ }^{21}$ At the end of the reaction, the mixture was concentrated to obtain precipitate of Schiff base which was filtered and recrystallized using ethyl acetate (Scheme 1). 5-(methyleneamino)-1,3,4-thiadiazole-2-thiol (2a): Yield $85 \%$; m.p. $66-68{ }^{\circ} \mathrm{C}$; FT-IR $\left(\mathrm{KBr}, \mathrm{cm}^{-1}\right): 1627$ (C=Nstr), 2545 (S-Hstr, thiol), 1225 (C-Nstr), 677 (C-S); ${ }^{1} \mathrm{H}$ NMR $\delta(400$ $\mathrm{MHz}, \mathrm{MeOD}, \mathrm{ppm}): \delta 3.65\left(2 \mathrm{H}, \mathrm{s},=\mathrm{CH}_{2}\right), 12.55(1 \mathrm{H}, \mathrm{s},-\mathrm{SH})$; ${ }^{13} \mathrm{C}$ NMR (100 MHz, MeOD, ppm): $\delta 166.82\left(=\mathrm{CH}_{2}\right), 185.21$ (C-2), 172.65 (C-5); Anal. Calcd for: $\mathrm{C}_{3} \mathrm{H}_{3} \mathrm{~N}_{3} \mathrm{~S}_{2}: \mathrm{C}, 24.85$; $\mathrm{H}$, 2.44; Found: C, 25.08; H, 2.56.

5-(ethylideneamino)-1,3,4-thiadiazole-2-thiol (2b): Yield $82 \%$; m.p. $56-58^{\circ} \mathrm{C}$; FT-IR ( $\left.\mathrm{KBr}, \mathrm{cm}^{-1}\right): 1630(\mathrm{C}=\mathrm{Nstr}), 2544$ (S-Hstr, thiol), 1228 (C-Nstr), 672 (C-S); ${ }^{1} \mathrm{H}$ NMR $\delta$ (400 $\left.\mathrm{MHz}, \mathrm{CDCl}_{3}, \mathrm{ppm}\right): \delta 1.22\left(3 \mathrm{H}, \mathrm{s},-\mathrm{CH}_{3}\right), 7.52(1 \mathrm{H}, \mathrm{s},=\mathrm{CH})$, $13.01(1 \mathrm{H}, \mathrm{s},-\mathrm{SH}) ;{ }^{13} \mathrm{C}$ NMR $\left(100 \mathrm{MHz}, \mathrm{CDCl}_{3}, \mathrm{ppm}\right): \delta$ $19.01\left(-\mathrm{CH}_{3}\right), 164.76(=\mathrm{CH}-), 184.11(\mathrm{C}-2), 169.65(\mathrm{C}-5)$; Anal. Calcd for: $\mathrm{C}_{4} \mathrm{H}_{5} \mathrm{~N}_{3} \mathrm{~S}_{2}$ : C, 31.27; H, 2.66; Found: C, 32.12; H, 2.90.

5-(propan-2-ylideneamino)-1,3,4-thiadiazole-2-thiol (2c): Yield $80 \%$; m.p. $60-62{ }^{\circ} \mathrm{C}$; FT-IR $\left(\mathrm{KBr}, \mathrm{cm}^{-1}\right): 1628$ (C=Nstr), 2546 (S-Hstr, thiol), 1231 (C-Nstr), 679 (C-Sstr); ${ }^{1} \mathrm{H}$ NMR $\delta\left(400 \mathrm{MHz}, \mathrm{CDCl}_{3}, \mathrm{ppm}\right): \delta 1.86\left(6 \mathrm{H}, \mathrm{s}, 2 \mathrm{x}-\mathrm{CH}_{3}\right)$, $12.84(1 \mathrm{H}, \mathrm{s},-\mathrm{SH}) ;{ }^{13} \mathrm{C}$ NMR $\left(100 \mathrm{MHz}, \mathrm{CDCl}_{3}, \mathrm{ppm}\right): \delta$ $21.22\left(-\mathrm{CH}_{3}\right), 172.81\left(=\mathrm{C}\left(\mathrm{CH}_{3}\right)_{2}\right), 184.20(\mathrm{C}-2), 168.24(\mathrm{C}-5)$; Anal. Calcd for: $\mathrm{C}_{5} \mathrm{H}_{7} \mathrm{~N}_{3} \mathrm{~S}_{2}: \mathrm{C}, 34.55 ; \mathrm{H}, 4.09$; Found: $\mathrm{C}$, 35.01; H, 4.56 .

5-(benzylideneamino)-1,3,4-thiadiazole-2-thiol (2d): Yield 61\%; m.p. $85-87^{\circ} \mathrm{C}$; FT-IR $\left(\mathrm{KBr}, \mathrm{cm}^{-1}\right): 1633(\mathrm{C}=\mathrm{Nstr}), 1581(\mathrm{C}=\mathrm{Cstr}$ of Ar), 2566 (S-Hstr, thiol), 1229 (C-Nstr), 684 (C-Sstr); ${ }^{1} \mathrm{H}$ NMR $\delta\left(400 \mathrm{MHz}, \mathrm{CDCl}_{3}, \mathrm{ppm}\right): \delta 8.21(1 \mathrm{H}, \mathrm{s},=\mathrm{CH}), 12.55(1 \mathrm{H}$, $\mathrm{s},-\mathrm{SH}), 7.56-7.86(5 \mathrm{H}, \mathrm{m}, \mathrm{Ar}-\mathrm{H}) ;{ }^{13} \mathrm{C}$ NMR $\left(100 \mathrm{MHz}, \mathrm{CDCl}_{3}\right.$, ppm): $\delta 21.41\left(-\mathrm{CH}_{3}\right), 162.56$ (=느- $), 185.22(\mathrm{C}-2), 167.39(\mathrm{C}-5)$, 127.22-137.15 (6C, Ar-C); Anal. Calcd for: $\mathrm{C}_{9} \mathrm{H}_{7} \mathrm{~N}_{3} \mathrm{~S}_{2}$ : C, 48.85; H, 3.22; Found: C, 48.96; H, 3.81 .

5-((1-phenylethylidene)amino)-1,3,4-thiadiazole-2-thiol (2e): Yield 50\%; m.p. $95-97{ }^{\circ} \mathrm{C}$; FT-IR $\left(\mathrm{KBr}, \mathrm{cm}^{-1}\right)$ : 1629 $(\mathrm{C}=\mathrm{N} s t r), 1585(\mathrm{C}=\mathrm{Cstr}$ of Ar), 2565 (S-Hstr, thiol), 1225 (CNstr), 679 (C-Sstr); ${ }^{1} \mathrm{H}$ NMR $\delta\left(400 \mathrm{MHz}, \mathrm{CDCl}_{3}, \mathrm{ppm}\right): \delta$ $1.89\left(3 \mathrm{H}, \mathrm{s},-\mathrm{CH}_{3}\right), 12.89(1 \mathrm{H}, \mathrm{s},-\mathrm{SH}), 7.66-7.89(5 \mathrm{H}, \mathrm{m}, \mathrm{Ar}-$ $\mathrm{H}) ;{ }^{13} \mathrm{C}$ NMR $\left(100 \mathrm{MHz}, \mathrm{CDCl}_{3}, \mathrm{ppm}\right): \delta 21.69\left(-\mathrm{CH}_{3}\right)$, $165.28\left(=\mathrm{C}\left(\mathrm{CH}_{3}\right)\right), 184.86(\mathrm{C}-2), 168.11(\mathrm{C}-5), 129.25-138.26$ (6C, Ar-C); Anal. Calcd for: $\mathrm{C}_{10} \mathrm{H}_{9} \mathrm{~N}_{3} \mathrm{~S}_{2}$ : C, 52.01; H, 3.91; Found: C, 52.88; H, 3.98. 


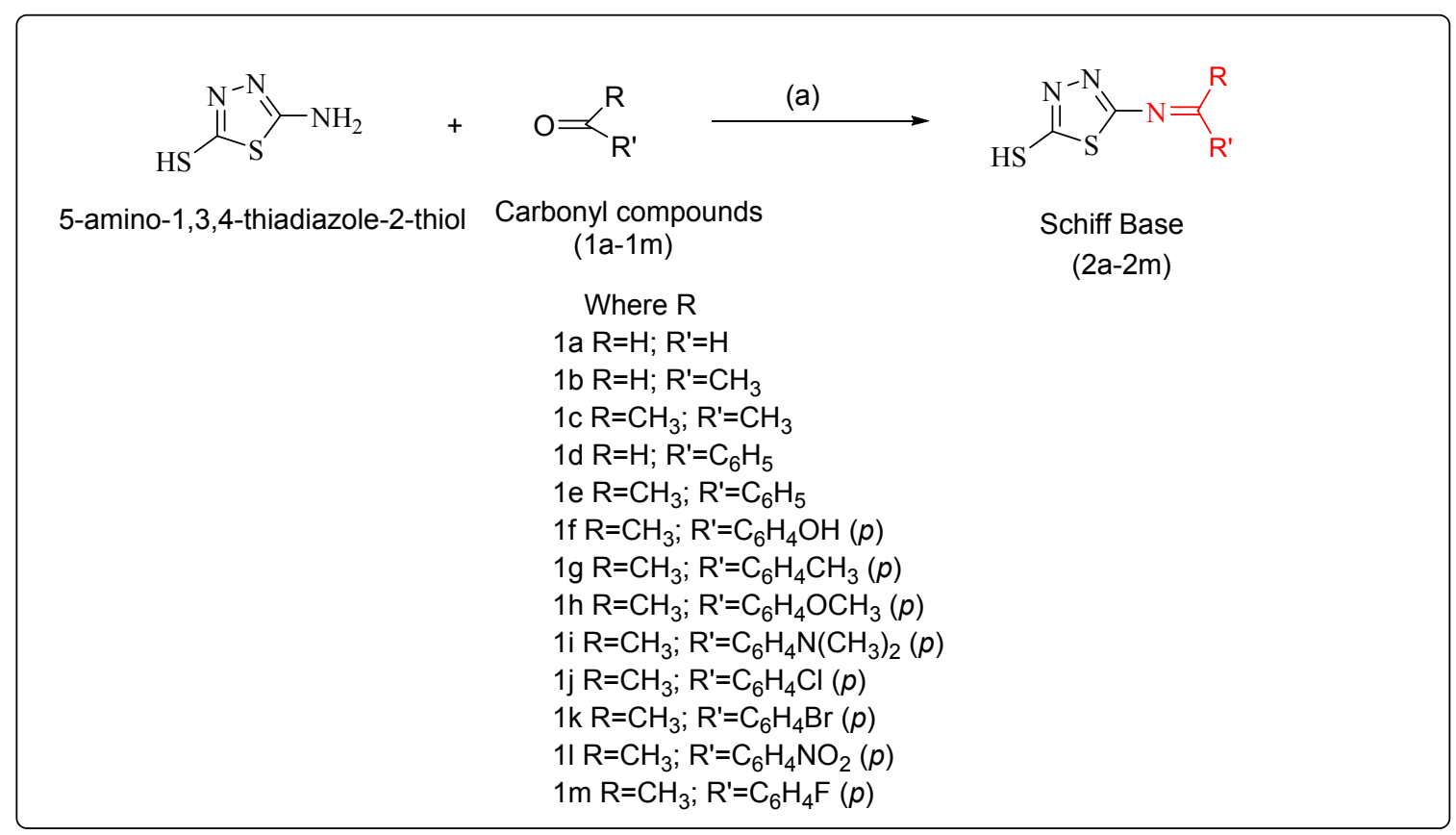

Scheme 1 - Synthetic route for the preparation of target Schiff base compounds (2a-2m). Reagents and conditions: (a) Dichloromethane, anhydrous $\mathrm{MgSO}_{4}$, stirring, room temperature, 2-4 h; (1a-1m) Different carbonyl compounds.

4-(((5-mercapto-1,3,4-thiadiazol-2-yl)imino)methyl)phenol (2f): Yield 58\%; m.p. $188-190{ }^{\circ} \mathrm{C}$; FT-IR (KBr, cm $\left.{ }^{-1}\right): 1636$ $(\mathrm{C}=\mathrm{N} s t r), 1588(\mathrm{C}=\mathrm{Cstr}$ of Ar), $2571(\mathrm{~S}-\mathrm{H} s t r$, thiol), $1232(\mathrm{C}-$ Nstr), 683 (C-Sstr), 3255 (Ar-OH); ${ }^{1} \mathrm{H}$ NMR $\delta(400 \mathrm{MHz}$, $\left.\mathrm{CDCl}_{3}, \mathrm{ppm}\right): 8.55(1 \mathrm{H}, \mathrm{s},=\mathrm{CH}), 12.89(1 \mathrm{H}, \mathrm{s},-\mathrm{SH}), 6.91-$ 7.79 (4H, m, Ar-H), $5.28(1 \mathrm{H}, \mathrm{Ar}-\mathrm{OH}) ;{ }^{13} \mathrm{C}$ NMR $(100 \mathrm{MHz}$, $\left.\mathrm{CDCl}_{3}, \mathrm{ppm}\right): \delta 165.23$ (=CH-), 186.57 (C-2), 164.54 (C-5), 162.12 (Ar-C-OH), 118.25-135.36 (5C, Ar-C); Anal. Calcd for: $\mathrm{C}_{9} \mathrm{H}_{7} \mathrm{~N}_{3} \mathrm{~S}_{2} \mathrm{O}$ : C, 46.25; H, 2.88; Found: C, 46.91; H, 3.19.

\section{5-((4-methylbenzylidene)amino)-1,3,4-thiadiazole-2-thiol} (2g): Yield 56\%; m.p. $116-118^{\circ} \mathrm{C}$; FT-IR $\left(\mathrm{KBr}, \mathrm{cm}^{-1}\right): 1631$ $(\mathrm{C}=\mathrm{N} s t r), 1583(\mathrm{C}=\mathrm{Cstr}$ of Ar), 2569 (S-Hstr, thiol), 1235 (CNstr), 689 (C-Sstr): ${ }^{1} \mathrm{H}$ NMR $\delta\left(400 \mathrm{MHz}, \mathrm{CDCl}_{3}, \mathrm{ppm}\right): 8.62$ $(1 \mathrm{H}, \mathrm{s},=\mathrm{CH}), 12.98(1 \mathrm{H}, \mathrm{s},-\mathrm{SH}), 7.22-7.85(4 \mathrm{H}, \mathrm{m}, \mathrm{Ar}-\mathrm{H})$, $2.25\left(3 \mathrm{H}, \mathrm{s},-\mathrm{CH}_{3}\right) ;{ }^{13} \mathrm{C}$ NMR $\left(100 \mathrm{MHz}, \mathrm{CDCl}_{3}, \mathrm{ppm}\right): \delta$ $163.56\left(=\underline{\mathrm{C}}\left(\mathrm{CH}_{3}\right)\right), 185.92(\mathrm{C}-2), 166.23(\mathrm{C}-5), 128.65-141.45$ (6C, Ar-C), $22.35\left(\mathrm{Ar}-\mathrm{CH}_{3}\right)$; Anal. Calcd for: $\mathrm{C}_{10} \mathrm{H}_{9} \mathrm{~N}_{3} \mathrm{~S}_{2}$ : C, 51.61; H, 3.85; Found: C, 52.02; H, 4.16 .

\section{5-((4-methoxybenzylidene)amino)-1,3,4-thiadiazole-2-thiol}

(2h): Yield58\%; m.p. $120-122{ }^{\circ} \mathrm{C}$; FT-IR (KBr, cm $\left.{ }^{-1}\right): 1643$ $(\mathrm{C}=\mathrm{N} s t r), 1594(\mathrm{C}=\mathrm{Cstr}$ of $\mathrm{Ar}), 2577$ (S-Hstr, thiol), 1247 (CNstr), 695 (C-Sstr); ${ }^{1} \mathrm{H}$ NMR $\delta\left(400 \mathrm{MHz}, \mathrm{CDCl}_{3}, \mathrm{ppm}\right): 8.59$ $(1 \mathrm{H}, \mathrm{s},=\mathrm{CH}), 13.12(1 \mathrm{H}, \mathrm{s},-\mathrm{SH}), 7.12-7.45(4 \mathrm{H}, \mathrm{m}, \mathrm{Ar}-\mathrm{H})$, $3.85\left(3 \mathrm{H}, \mathrm{s},-\mathrm{CH}_{3}\right) ;{ }^{13} \mathrm{C} \mathrm{NMR}\left(100 \mathrm{MHz}, \mathrm{CDCl}_{3}, \mathrm{ppm}\right): \delta$ $161.7\left(=\mathrm{C}\left(\mathrm{CH}_{3}\right)\right), 184.92(\mathrm{C}-2), 163.23(\mathrm{C}-5), 114.62-161.23$ (6C, Ar-C), $56.35\left(\mathrm{Ar}-\mathrm{OCH}_{3}\right)$; Anal. Calcd for: $\mathrm{C}_{10} \mathrm{H}_{9} \mathrm{~N}_{3} \mathrm{OS}_{2}$ : C, 47.79; H, 3.61; Found: C, 49.02; H, 4.06.

\section{5-((4-(dimethylamino)benzylidene)amino)-1,3,4-thiadiazole-2-} thiol (2i): Yield 59\%; m.p. $124-126^{\circ} \mathrm{C}$; FT-IR $\left(\mathrm{KBr}, \mathrm{cm}^{-1}\right)$ : 1656 $(\mathrm{C}=\mathrm{N} s t r), 1598(\mathrm{C}=\mathrm{Cstr}$ of Ar), 2575 (S-Hstr, thiol), 1235 (CNstr), 693 (C-Sstr); ${ }^{1} \mathrm{H}$ NMR $\delta\left(400 \mathrm{MHz}, \mathrm{CDCl}_{3}, \mathrm{ppm}\right): 8.52$ $(1 \mathrm{H}, \mathrm{s},=\mathrm{CH}), 13.98(1 \mathrm{H}, \mathrm{s},-\mathrm{SH}), 6.83-7.62(4 \mathrm{H}, \mathrm{m}, \mathrm{Ar}-\mathrm{H}), 2.88$ $\left(6 \mathrm{H}, \mathrm{s},-\mathrm{N}\left(\mathrm{CH}_{3}\right)_{2}\right) ;{ }^{13} \mathrm{C} \mathrm{NMR}\left(100 \mathrm{MHz}, \mathrm{CDCl}_{3}, \mathrm{ppm}\right): \delta 162.576$ $\left(=\mathrm{C}\left(\mathrm{CH}_{3}\right)\right), 184.92$ (C-2), 155.12 (C-5), 120.37-129.20 (6C, ArC), $42.35\left(\mathrm{Ar}-\mathrm{N}\left(\mathrm{CH}_{3}\right)_{2}\right)$; Anal. Calcd for: $\mathrm{C}_{11} \mathrm{H}_{12} \mathrm{~N}_{4} \mathrm{~S}_{2}$ : C, 51.27; H, 4.46; Found: C, 54.72; H, 5.03 . 5-((4-chlorobenzylidene)amino)-1,3,4-thiadiazole-2-thiol (2j): Yield 86\%; m.p. $118-120{ }^{\circ} \mathrm{C}$; FT-IR (KBr, $\left.\mathrm{cm}^{-1}\right)$ : 1637 $(\mathrm{C}=\mathrm{N} s t r), 1569(\mathrm{C}=\mathrm{Cs} t r$ of $\mathrm{Ar}), 2569$ (S-Hstr, thiol), 1231 (C$\mathrm{N} s t r), 692$ (C-Sstr); ${ }^{1} \mathrm{H}$ NMR $\delta\left(400 \mathrm{MHz}, \mathrm{CDCl}_{3}, \mathrm{ppm}\right): 8.62$ $(1 \mathrm{H}, \mathrm{s},=\mathrm{CH}), 13.68(1 \mathrm{H}, \mathrm{s},-\mathrm{SH}), 7.62-7.94(4 \mathrm{H}, \mathrm{m}, \mathrm{Ar}-\mathrm{H})$, $2.25 ;{ }^{13} \mathrm{C}$ NMR $\left(100 \mathrm{MHz}, \mathrm{CDCl}_{3}, \mathrm{ppm}\right): \delta 161.76\left(=\mathrm{C}\left(\mathrm{CH}_{3}\right)\right)$, 185.73 (C-2), 130.04 (C-5), 129.9-139.80 (6C, Ar-C); Anal. Calcd for: $\mathrm{C}_{9} \mathrm{H}_{6} \mathrm{ClN}_{3} \mathrm{~S}_{2}: \mathrm{C}, 43.89$; H, 2.95; Found: C, 46.37; $\mathrm{H}, 3.97$.

\section{5-((4-bromobenzylidene)amino)-1,3,4-thiadiazole-2-thiol} (2k): Yield 72\%; m.p. $116-118^{\circ} \mathrm{C}$; FT-IR $\left(\mathrm{KBr}, \mathrm{cm}^{-1}\right)$ : 1631 (C=Nstr), 1583 (C=Cstr of Ar), 2569 (S-Hstr, thiol), 1235 (CNstr), 689 (C-Sstr); ${ }^{1} \mathrm{H}$ NMR $\delta\left(400 \mathrm{MHz}, \mathrm{CDCl}_{3}, \mathrm{ppm}\right): 8.98$ $(1 \mathrm{H}, \mathrm{s},=\mathrm{CH}), 13.46(1 \mathrm{H}, \mathrm{s},-\mathrm{SH}), 7.81-8.825(4 \mathrm{H}, \mathrm{m}, \mathrm{Ar}-\mathrm{H})$; ${ }^{13} \mathrm{C}$ NMR $\left(100 \mathrm{MHz}, \mathrm{CDCl}_{3}, \mathrm{ppm}\right): \delta 161.96\left(=\mathrm{C}\left(\mathrm{CH}_{3}\right)\right)$, 185.21 (C-2), 132.38 (C-5), 125.38-1315.42 (6C, Ar-C); Anal. Calcd for: $\mathrm{C}_{9} \mathrm{H}_{6} \mathrm{BrN}_{3} \mathrm{~S}_{2}$ : C, 37.73; H, 2.94; Found: C, 39.64; H, 3.69.

5-((4-nitrobenzylidene)amino)-1,3,4-thiadiazole-2-thiol (21): Yield 78\%; m.p. $116-118{ }^{\circ} \mathrm{C}$; FT-IR $\left(\mathrm{KBr}, \mathrm{cm}^{-1}\right): 1634$ $(\mathrm{C}=\mathrm{N} s t r), 1588(\mathrm{C}=\mathrm{Cstr}$ of Ar), 2577 (S-Hstr, thiol), 1242 (CNstr), 687 (C-Sstr); ${ }^{1} \mathrm{H}$ NMR $\delta\left(400 \mathrm{MHz}, \mathrm{CDCl}_{3}, \mathrm{ppm}\right): 8.85$ $(1 \mathrm{H}, \mathrm{s},=\mathrm{CH}), 13.73(1 \mathrm{H}, \mathrm{s},-\mathrm{SH}), 8.78-9.15(4 \mathrm{H}, \mathrm{m}, \mathrm{Ar}-\mathrm{H})$, $2.25 ;{ }^{13} \mathrm{C}$ NMR $\left(100 \mathrm{MHz}, \mathrm{CDCl}_{3}, \mathrm{ppm}\right): \delta 161.76\left(=\mathrm{C}\left(\mathrm{CH}_{3}\right)\right)$, 185.13 (C-2), 125.42 (C-5), 126.37-151.45 (6C, Ar-C), 150.35 (Ar-NO2); Anal. Calcd for: $\mathrm{C}_{9} \mathrm{H}_{6} \mathrm{~N}_{4} \mathrm{O}_{2} \mathrm{~S}_{2}$ : C, 42.31; $\mathrm{H}, 2.97$; Found: C, 45.42; H, 3.79.

\section{5-((4-fluorobenzylidene)amino)-1,3,4-thiadiazole-2-thiol} (2m): Yield 80\%; m.p. $116-118{ }^{\circ} \mathrm{C}$; FT-IR $\left(\mathrm{KBr}, \mathrm{cm}^{-1}\right)$ : 1635 $(\mathrm{C}=\mathrm{N} s t r), 1589$ (C=Cstr of Ar), 2573 (S-Hstr, thiol), 1249 (CNstr), 692 (C-Sstr); ${ }^{1} \mathrm{H}$ NMR $\delta\left(400 \mathrm{MHz}, \mathrm{CDCl}_{3}, \mathrm{ppm}\right): 8.86$ $(1 \mathrm{H}, \mathrm{s},=\mathrm{CH}), 13.74(1 \mathrm{H}, \mathrm{s},-\mathrm{SH}), 7.57-8.13(4 \mathrm{H}, \mathrm{m}, \mathrm{Ar}-\mathrm{H})$; ${ }^{13} \mathrm{C}$ NMR (100 MHz, $\left.\mathrm{CDCl}_{3}, \mathrm{ppm}\right): \delta 161.26\left(=\mathrm{C}\left(\mathrm{CH}_{3}\right)\right)$, 184.98 (C-2), 116.19 (C-5), 116.19.65-164.37 (6C, Ar-C); Anal. Calcd for: $\mathrm{C}_{9} \mathrm{H}_{6} \mathrm{FN}_{3} \mathrm{~S}_{2}$ : C, 47.17.61; H, 2.95; Found: C, 49.84; H, 4.10 . 


\section{Biological studies}

In vitro antibacterial and antifungal activities: The antimicrobial activity was performed against two bacterial and two fungal strains by serial tube dilution method and minimum inhibitory concentration (MIC) of all the compounds were determined against the selected microbes. ${ }^{22,23}$ The bacterial strains selected for the study were Staphylococcus aureus (NCIM-2063, Sa) and Proteus vulgaris (NCIM-2027, $P v$ ) whereas the fungal strains include Aspergillus niger (ATCC-6275, An) and Candida tropicalis (ATCC-1369, Ca) respectively. Ciprofloxacin and fluconazole were used as positive controls for the antibacterial and antifungal activities respectively. Antibacterial activity was performed using nutrient agar medium whereas PotatoDextrose-Agar medium was used for antifungal testing. All the experiments were carried out in triplicate and the results are presented as the mean of three independent experiments. $1.024 \mathrm{mg} / \mathrm{mL}$ concentration of each sample was obtained by dissolving $2.048 \mathrm{mg}$ of each test compound using methanol in a separate vial. The microbial strains were grown at $37^{\circ} \mathrm{C}$ in their respective nutrient medium and diluted in sterile nutrient broth medium to get a suspension containing $10^{7}$ cells $/ \mathrm{mL}$ and this suspension was used as the inoculum. 11 test tubes were selected and among them, 9 test tubes were marked the numbers 1-9 and the other two were assigned as $T_{M}$ (medium), and $\mathrm{T}_{\mathrm{MI}}$ (medium and inoculum). $1 \mathrm{~mL}$ of nutrient broth medium was poured into all the 11 test tubes and plugged with cotton and sterilized in an autoclave at $15 \mathrm{lbs} / \mathrm{sq}$.in pressure. Later, the test tubes were cooled and $1 \mathrm{~mL}$ of the sample solution was added to the first test tube and mixed well and then $1 \mathrm{~mL}$ of this content was transferred to the second test tube and the process of serial dilution was continued up to the ninth test tube. All the nine test tubes and the test tube $\mathrm{T}_{\mathrm{MI}}$ were charged with $10 \mu \mathrm{L}$ of properly diluted inoculum and mixed well. However, the controlled test tube $T_{M}$ containing only the medium was used to confirm the sterility of the medium. All the test tubes were incubated for $18 \mathrm{~h}$ at $37^{\circ} \mathrm{C}$. A similar experiment with inoculum, medium and methanol without compound was furthermore performed to confirm that there is no inhibitory effect of methanol used for the dilutions. The test tube number in which the first sign of the growth of the organism observed was noted using a spectrophotometer. The MIC was determined for all the compounds by taking that concentration used in the test tube number just before the test tube number where the first sign of growth observed.

In vitro antitubercular activity studies: All the test compounds were evaluated for their preliminary antimycobacterial activity against $M$. tuberculosis $\mathrm{H}_{37} \mathrm{Rv}$ by broth dilution assay to determine their MIC. A frozen culture in Middle brook $7 \mathrm{H} 9$ broth supplemented with $0.2 \%$ glycerol and $10 \%$ albumin-dextrose-catalase was defrosted and diluted in broth to $10^{5} \mathrm{cfu} \mathrm{mL}^{-1}$ (colony forming unit $/ \mathrm{mL}$ ) dilutions. Each test compound was dissolved in DMSO and then diluted in broth twice at the desired concentration. The final concentration of DMSO in the assay medium was $1.3 \%$. Each U-tube was then inoculated with $0.05 \mathrm{~mL}$ of standardized culture and then incubated at $37{ }^{\circ} \mathrm{C}$ for 21 days. ${ }^{24-26}$ The growth in the U-tubes was compared with visibility against positive control (without drug), negative control (without drug and inoculum) and with standard pyrazinamide. The activity was performed in triplicate and the results are recorded as the mean of three independent experiments.

\section{RESULTS AND DISCUSSION}

\section{Chemistry}

Condensation of 5-amino-1,3,4-thiadiazole-2thiol with different carbonyl compounds (1a-m) by using magnesium sulfate catalyst at room temperature afforded the target Schiff base compounds (2a-m) with different yields. Schiff bases formed due to the reaction of carbonyl compounds with aliphatic chain had produced high yields of the product compared to the aromatic counters. And among the aromatic carbonyl compounds the molecules with electron withdrawing halogen atoms $(-\mathrm{Cl}, \mathrm{Br}$ and $-\mathrm{F})$ and nitro group had produced compounds in high yields. The structures of the compounds were elucidated by the spectroscopic studies and elemental analysis. FT-IR spectrum revealed the presence of characteristic bands for $\mathrm{C}=\mathrm{N} s t r\left(1627-1656 \mathrm{~cm}^{-1}\right), 2545 \mathrm{~S}-\mathrm{H} s t r(2544-2577)$, C-Nstr (1225-1249) and C-S (672-695) and there is nonexistence of any bands for the carbonyl or the primary amino group. The ${ }^{1} \mathrm{H}$ NMR spectrum recorded the characteristic singlet for unsubstituted and mono-substituted imino hydrogens around the chemical shift values $3.65\left(=\mathrm{CH}_{2}\right)$ and 7.52-8.98 $(=\mathrm{CH})$. The signals around 6-8 ppm has been assigned for the protons on the aromatic rings. Two compounds $\mathbf{2 c}$ and $2 \mathbf{e}$ had not showed such singlet peak due to the lack of such hydrogen. A singlet peak for thiol (-SH) proton is seen around $\delta$ 12.55-13.98. The compounds in their ${ }^{13} \mathrm{C}$ NMR spectrum had shown three diagnostic peaks for the imino carbon (161.26-172.81), C-2 (184.11-186.57) and C-5 (116.19-172.65). Elemental analysis data for the elements carbon and hydrogen were found within + $0.4 \%$ of the calculated values.

\section{Biological studies}

The MIC values of Schiff bases (2a-2m) designate that the newly synthesized compounds possess moderate to excellent antibacterial and antifungal activities against the tested pathogenic bacteria compared to the positive control's ciprofloxacin and fluconazole. The results are summarized in Table 1 which is the average of the three experiments. The Schiff bases containing the substituted benzaldehyde moieties i.e., $\mathbf{2 d}, \mathbf{2 f}, \mathbf{2 g}$, $\mathbf{2 h}, \mathbf{2 i}, \mathbf{2 j}, \mathbf{2 k}, \mathbf{2 l}$ and $\mathbf{2 m}$ showed potent activities than the Schiff bases prepared from formaldehyde and acetaldehyde (2a and $\mathbf{2 b}$ ), acetone (2c), acetophenone (2e) and benzaldehyde (2d). 
Table 1

Biological screening data of the target Schiff base compounds (2a-2m)

\begin{tabular}{|c|c|c|c|c|c|c|}
\hline S.No & Entry & \multicolumn{4}{|c|}{$\begin{array}{l}\text { Antibacterial and antifungal activities } \\
(\text { (MIC in } \mu \mathrm{g} / \mathrm{mL})^{\mathrm{a}}\end{array}$} & \multirow{2}{*}{$\begin{array}{l}\text { Antitubercular activity } \\
(\mathrm{MIC} \text { in } \mu \mathrm{g} / \mathrm{mL})^{\mathrm{a}}\end{array}$} \\
\hline \multicolumn{2}{|c|}{ Organisms } & $S a$ & $P v$ & $A n$ & $C t$ & \\
\hline 1 & $\mathbf{2 a}$ & 256 & 512 & 128 & 256 & 32 \\
\hline 2 & $2 \mathbf{b}$ & 256 & 256 & 128 & 128 & 32 \\
\hline 3 & $2 c$ & 128 & 128 & 64 & 64 & 32 \\
\hline 4 & 2d & 64 & 128 & 128 & 64 & 16 \\
\hline 5 & $2 e$ & 32 & 32 & 64 & 32 & 16 \\
\hline 6 & $2 f$ & 32 & 16 & 64 & 32 & 3.12 \\
\hline 7 & $2 \mathrm{~g}$ & 128 & 16 & 128 & 128 & 3.12 \\
\hline 8 & $2 \mathrm{~h}$ & 64 & 16 & 256 & 256 & 3.12 \\
\hline 9 & $2 \mathbf{i}$ & 64 & 8 & 128 & 256 & 3.12 \\
\hline 10 & $2 \mathbf{j}$ & 16 & 64 & 16 & 16 & 1 \\
\hline 11 & $2 \mathbf{k}$ & 16 & 64 & 16 & 16 & 2 \\
\hline 12 & 21 & 16 & 128 & 8 & 8 & 2 \\
\hline 13 & $2 m$ & 8 & 64 & 8 & 8 & 1 \\
\hline 14 & Ciprofloxacin & 16 & 16 & --- & --- & -- \\
\hline 15 & Fluconazole & --- & --- & 16 & 16 & -- \\
\hline 16 & Pyrazinamide & -- & --- & --- & --- & 3.12 \\
\hline
\end{tabular}

Sa: Staphylococcus aureus, Pv: Proteus vulgaris; An: Aspergillus niger; Ct: Candida tropicalis; Mt: Mycobacterium tuberculosis; MIC: Minimum inhibitory concentration. ${ }^{\text {a }} \mathrm{MIC}$ 's are mean of three experiments.

Compounds bearing electron withdrawing groups showed potent activity against gram positive Staphylococcus aureus and fungal organisms Aspergillus niger and Candida tropicalis with the MIC ranging from $8-16 \mu \mathrm{g} / \mathrm{mL}$. The compound $\mathbf{2 m}$ containing fluorine (-F) atom showed highest activity with a MIC of $8 \mu \mathrm{g} / \mathrm{mL}$ against Staphylococcus aureus and Aspergillus niger where as 2l holding a nitro $\left(-\mathrm{NO}_{2}\right)$ group demonstrated potent activity against Candida tropicalis (MIC $=8 \mu \mathrm{g} / \mathrm{mL}$ ). The activity of $\mathbf{2 m}$ and $\mathbf{2 l}$ is greater than the MIC $(16 \mu \mathrm{g} / \mathrm{mL})$ of the standard drugs. The other derivatives such as $\mathbf{2} \mathbf{j}$ and $\mathbf{2} \mathbf{k}$ possessing $-\mathrm{Cl}$ and $-\mathrm{Br}$ atom displayed activity equal to the standard drugs with the MIC $16 \mu \mathrm{g} / \mathrm{mL}$. Schiff bases armed with electron releasing groups (2f, $\mathbf{2 g}, \mathbf{2 h}$ and $\mathbf{2 i})$ possess excellent activity on Proteus vulgaris and among them $2 \mathbf{i}$ containing dimethyl amino group exhibited superior potency than the positive controls with MIC $8 \mu \mathrm{g} / \mathrm{mL}$, whereas $\mathbf{2 f}, \mathbf{2 g}$ and $\mathbf{2 h}$ were equipotent as standard drugs. The potent antibacterial activity shown by the aryl ring substituted with halogens like fluorine, chlorine and bromine on the Schiff bases derived from 5amino-1,3,4-thiadiazole-2-thiol and less activity of alkylated Schiff bases is in accordance with the previous studies by Oana $\mathrm{Rad}$ et al., ${ }^{27}$ and Mohammed et al. ${ }^{28}$ Husam et al., had studied the antifungal activity of 4-(( (5-mercapto-1,3,4thiadiazol-2-yl)imino)methyl)-2-methoxyphenol containing phenyl ring substituted with two electron-releasing groups $\left(-\mathrm{OCH}_{3}\right.$ and $\left.-\mathrm{OH}\right)$ against Candida albicans and found potent activity than ketoconazole. ${ }^{29}$ In our case the compounds with electron-withdrawing halogen atoms at para position had shown promising activity than the compounds with single electron-releasing group like hydroxy or methoxy groups. This suggests the altering the nature and position of different substituents on the aryl ring will have a great impact on the antifungal activity of Schiff bases derived from 5-amino-1,3,4-thiadiazole-2-thiol.

Compounds $\mathbf{2 f}, \mathbf{2 g}, \mathbf{2 h}$ and $\mathbf{2 i}$ showed similar antitubercular activity $(\mathrm{MIC}=3.125 \mu \mathrm{g} / \mathrm{mL}$ ) as pyrazinamide on the tested Mycobacterium tuberculosis $\mathrm{H}_{37} \mathrm{Rv}$ strain whereas $\mathbf{2 a}, \mathbf{2 b}, \mathbf{2 c}, \mathbf{2 d}$ and $2 \mathrm{e}$ displayed poor activity with MIC ranging from $8-32 \mu \mathrm{g} / \mathrm{mL}$ (Table 1 ). The activity of $\mathbf{2} \mathbf{j}, \mathbf{2} \mathbf{k}$, 2l and $\mathbf{2 m}$ was greater than the standard pyrazinamide. And among these four compounds $\mathbf{2 m}$ and $\mathbf{2 j}$ bearing fluorophenyl and chlorophenyl scaffolds were the most active antitubercular compounds with MIC $1 \mu \mathrm{g} / \mathrm{mL}$ where as $\mathbf{2 k}$ and $\mathbf{2 l}$ holding bromophenyl and nitrophenyl moieties had the MIC $2 \mu \mathrm{g} / \mathrm{mL}$.

\section{CONCLUSIONS}

5-Amino-2-mercapto-1,3,4-thiazole based Schiff bases were prepared in moderate to good 
yields by simple organic synthesis method and evaluated for their antibacterial, antifungal and antitubercular activities. The preliminary biological testing has provided some interesting results. There is predominance of the antitubercular activity. The positive results indicate that these scaffolds will be the new lead molecules for the development of therapeutic agents against tuberculosis infections. However, further studies need to be carried out in order to predict the mode of action, toxicities and inhibitory effect on the resistant microbial strains.

\section{REFERENCES}

1. S. D. Chandra, R. D. V. Venkata, R. A. Tejaswara, U. Lavkumar and J. Anjali, Russ. J. Gen. Chem., 2019, 89, 770 .

2. S. M. Gomha, M. M. Edrees, Z. A. Muhammad and A. A. El-reedy, Drug Des. Dev. Ther., 2018, 2018, 1511.

3. M. G. Sobhi, A. K. Nabila, R. A. Mohamad, N. M. Yahia and M. A. Ahmad, Chem. Cent. J., 2017, 11, 1.

4. C. Jixiang, Y. Chongfen, W. Shaobo, W. Sikai, L. Shaoyuan and H. Deyu, Bioorg. Med. Chem. Lett., 2019, 29, 1203.

5. T. Ebru, B. Hacer, E. Mehtap, K. Sengulalpay and B. Arif, Bioorg. Chem., 2019, 89, 10299.

6. E. Mustafa, T. Hakan, K. Tuncay and O. Abdurrahman, J. Heterocycl. Chem., 2019, 9, 2555.

7. C. Barbara, B. Katarzyna, D. Wojciech, P. Daniel, N. Andrzej, O. Alina, M. Katarzyna and G. Mariusz, Sci. Rep., 2019, 9, 1.

8. C. Zi-Ning, L. Ya-Sheng, H. De-Kun, T. Hao, J. JiaZhen, W. Yuan and J. Xiao, Sci. Rep., 2016, 6, 1.

9. K. Sevgi and R. Sevim, Marmara Pharm J., 2016, 20, 199.
10. P. Harun, J. Harsha, A. Iqrar, P. Rahul and S. Sanjay, Eur. J. Med. Chem., 2019, 167, 1.

11. J. Katarina, D. J. Milan, B. Bruno, S. J. Ljiljana, A. Edina, M. Zoran, M. Vladimir, A. Marijana, T. Snežana and M. Violeta, C. R. Chim., 2019, 22, 585.

12. J. Katarina, Z. M. Ivana, S. Tatjana, K. Ana, M. Violeta and D. J. Milan, M. Nevena, N. Marija and J. Ljubinka, Bioorg. Med. Chem. Lett., 2017, 27, 3709.

13. S. Bushra, G. Raghed, A. Kahtan and A. Asker, $A d v$. Appl. Sci. Res., 2017, 8, 4.

14. S. G. Nayak and B. Poojary, Heliyon., 2019, 5, 1.

15. S. Siham, F. Adeline, L. Gerald, A. Amina and E. Abdelkrim, Heteroatom Chemistry., 2019, 2019, 1.

16. M. Ganesh, R. Darshana, K. Aruna and B. Sakina, J. Saudi Chem. Soc., 2017, 21, 954.

17. T. Syed and K. Geetha, Ind. J. Adv. Chem. Sci., 2016, 4, 40.

18. W. Yan-Yan, X. Fang-Zhou, Z. Yun-Ying, S. Baoan, L. Dexia and Y. Gang, C. Shunhong, X. Wei and W. Jian, Bioorg. Med. Chem. Lett., 2018, 28, 2979.

19. A. Kavitha, S. Anandhavelu, D. Easwaramoorthy, K. Karuppasamy, K. Hyun-Seok and V. Dhanasekaran, Sci. Rep., 2018, 8, 3054.

20. H. Qi-Meige, X. YanFan, H. Dong-Cheng and L. JiaCheng, Polyhedron., 2016, 109, 75-80.

21. Z. Yang and P. Sun, Molbank., 2006, 2006, M514.

22. J. M. Andrews, J. Antimicrob. Chemother., 2001, 48, 5.

23. A. B. Shaik, Y. R. Prasad and S. Shahanaaz, Int. J. Med. Chem., 2017, 2017, 1.

24. M. J. Hearn, PCT Int. Appl., 2002, 137, 20296.

25. S. Goto, K. Jo, T. Kawakita, S. Misuhashi, T. Nishino, N. Ohasawa and N. Tanami, Chemotherapy., 1981, $29,6$.

26. A. B. Shaik, L. S. V. Katti, P. S. Babu, S. Afreen, K. Supraja and H. K. Sai, Biointerface Res. Appl. Chem., 2019, 9, 3912.

27. O. Rada, R. Tibora, M. Dumab, L. Vlasec, A. Pîrnăud, B. Tiperciuca, I. Ionuța and O. Oniga, Stud. UBB. Chem., 2016, LXI, 17.

28. M. M. Saleh, S. F. AL-Joubori and B. F. AL- Thamiar, Baghdad Sci. J., 2007, 4, 89.

29. H. A. Ameen and A. J. Qasir, Iraqi. J. Pharm. Sci., 2012, 21,98 . 